\title{
Natura 2000 habitat mapping in Kattegat, Denmark: an example from Læsø Trindel
}

\author{
Zyad K. Al-Hamdani and Laura G. Addington
}

Natura 2000 is a network of nature protection areas established by the European Union under the Habitats Directive (European Union 1992). The aim is to assure long-term survival of the most valuable and endangered species and habitats in Europe. The network comprises special areas of conservation and protection designated by the member states under, respectively, the Habitats Directive and the Birds Directive. The establishment of the network of protected areas also fulfils a community obligation under the Convention of Biological Diversity of the United Nations.

The member states of the European Union are obliged to ensure full compliance with Natura 2000 legislation and must work out a management plan for each Natura 2000 area. In the marine environment, detailed information on the Natura 2000 areas is necessary to make informed management plans in fulfilment of national and international obligations and regulate human activities. The data may come from geophysical mapping or from biological sampling or from both.

This paper presents some of the results of a habitat mapping project performed in 2011 covering almost all Natura 2000 areas and pre-designated, aggregate extraction areas in the inner Danish waters. Due to time and resource limitations, the Natura 2000 areas in Danish waters were mapped by geophysical methods to produce seabed sediment maps, followed by biological sampling at selected stations. This is a fast and reliable method for producing a broad-scale habitat map of large areas in a limited time.

The areas were mapped and classified according to the Habitats Directive (European Union 1992; European Commission 2007). The mapping was also conducted to conform to the Marine Strategy Framework Directive, which requires the member states to provide an initial assessment of their marine waters by July 2012 (European Union 2008).

The Geological Survey of Denmark and Greenland (GEUS) carried out the geological and geophysical work, and Orbicon A/S undertook the biological investigations in 18 Natura 2000 areas in Kattegat and the southern Baltic Sea (Fig. 1). Læsø Trindel is a Natura 2000 area with a significant biodiversity and a wide range of habitat types of which three are of special interest: (1) boulder reefs, (2) sandbanks and (3) 'bubbling reefs' which are structures formed by leaking gas.

\section{Geological setting}

Læsø Trindel is located north-east of Læsø, the largest island in Kattegat. The Læsø Trindel area is located in the NWSE-trending Fennoscandian Border Zone and has been affected by neotectonic deformation (Hansen 1995). In this area there is a succession of Weichselian clay and silt with scattered stones and boulders, locally overlain by till. After isostatic rebound and erosion of the sediments in the Holocene, a widespread residual layer of boulders or patches of boulders has been left. Hermansen \& Jensen (2000) produced a regional (1:500 000 scale) seabed sediment map of the Danish waters, which shows the presence of till deposits in the area on and around Læsø Trindel. However, at that time there were insufficient data for a detailed sediment map of the area.

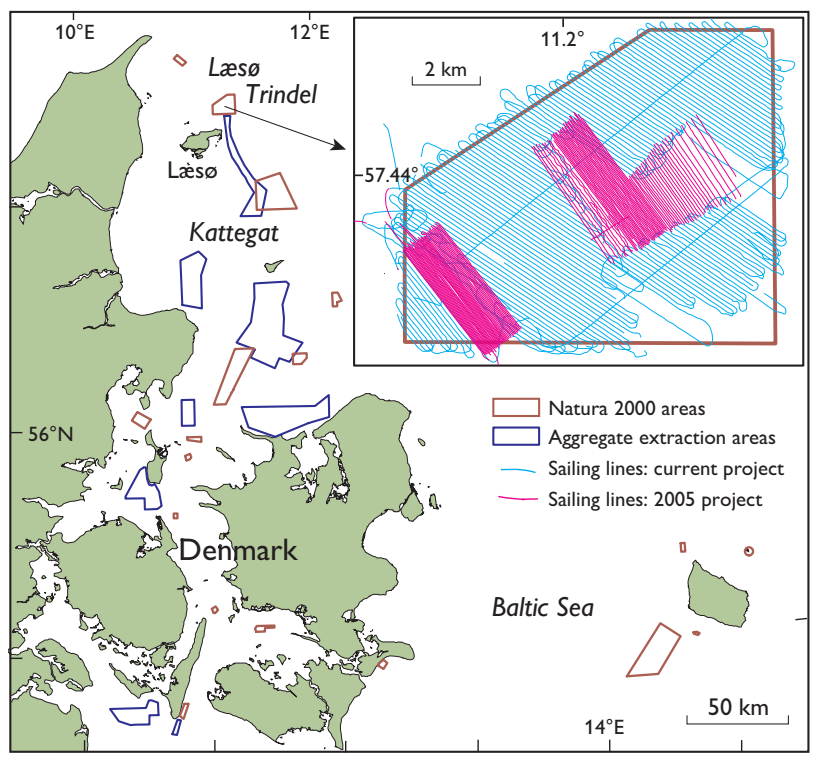

Fig. 1. Map of inner waters in Denmark showing the locations of the Natura 2000 and the aggregate extraction areas mapped in 2011. Inset: 2005 and 2011 sailing lines in the Læsø Trindel area. 


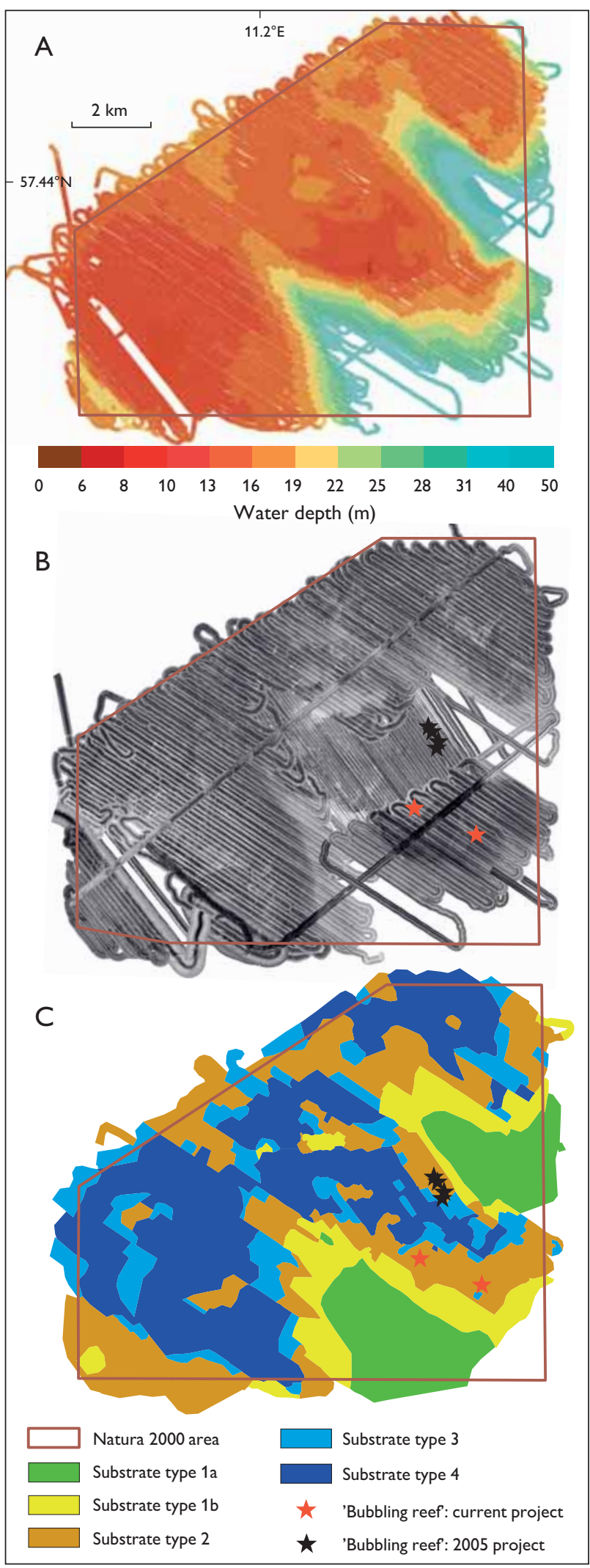

Fig. 2. The Læsø Trindel Natura 2000 area. A: Bathymetry. B: Side-scan sonar mosaic. The grey scale reflects hard (dark) to soft (light) sediments. C: Interpreted distribution of substrate types and Natura 2000 habitats.
A more recent study undertaken by GEUS in 2005 yielded echo sounder, side-scan sonar and ground truth data from the central part of Læsø Trindel (Fig. 1; Leth \& Al-Hamdani 2008) showing that it consists of a $2 \times 2 \mathrm{~km}$ shallow platform with water depths of 4 to $13 \mathrm{~m}$. In the eastern and south-eastern parts of the survey area, the water depth increases to $45 \mathrm{~m}$ (Fig. 2A). The platform consists mainly of till with boulders and cobbles that vary in size and distribution throughout the area. Its central part shows the highest density of cobbles and boulders, and this is the main boulder reef of the region. The surrounding part is characterised by gravelly sand and sand patches with scattered boulders.

\section{Methods}

Field work in 2011 was carried out in two phases: In phase one, bathymetry data were collected with a single-beam echo sounder, and overlapping seabed backscatter images were obtained using side-scan sonar with 100 and $400 \mathrm{kHz}$ frequencies. Information on the sub-bottom layers was obtained with a chirp profiler $(1-10 \mathrm{kHz}$; providing high resolution but low penetration) and a sparker $(1 \mathrm{kHz}$; providing deeper penetration but lower resolution). The area was surveyed with $100 \mathrm{~m}$ line spacing to ensure full seabed coverage. Cross lines with $4 \mathrm{~km}$ spacing were surveyed for cross-verification (Fig. 1).

In phase two, which succeeded preliminary interpretation of the acoustic data, areas of special interest were video filmed with a camera mounted on a remotely operated vehicle, and surface sediment samples were collected with a Van Veen grab sampler. Finally, sediment cores were collected with a $6 \mathrm{~m}$ long vibrocorer. The acoustic data, the video films and the grab and core samples were used together with older data for the final interpretation and habitat mapping .

\section{Results and discussion}

The data from 2005 and 2011 cover almost the entire Læsø Trindel Natura 2000 area (Fig. 1) and were used to map the bathymetry along the sailing lines, to compile a side-scan mosaic and to map the distribution of various substrates and nature types. The depth data from 2011 compare well with the depth data from 2005 which were acquired with a highly accurate multibeam echo sounder (Fig. 2A).

The side-scan backscatter mosaic image shows variation in substrate reflectivity due to the different signatures of the different sediments (Fig. 2B). The interpretation of the image was carried out by dividing the image into $50 \times 50 \mathrm{~m}$ blocks and manually classifying the sediments in each block. 
Interpretation of the side-scan images together with ground truth samples allowed us to produce a map that shows the distribution of substrate types and the occurrence of Natura 2000 habitat types, using the classification categories suggested by the Danish Nature Agency (Table 1; Fig. 2C). The chirp profiles were also used for the interpretation. The different types of sediments give different seismic signals that enhance the final seabed sediment interpretation significantly.

Boulder reefs (substrate type 4) cover c. 38\% of the $\mathrm{Na}$ tura 2000 area. Between these, substrate type 2 with sand and scattered boulders dominates. The deeper south-eastern parts of the surveyed area are dominated by soft sediment. Sandbanks are not well defined in the Læsø Trindel area, but
Table 1. Substrate classification

\begin{tabular}{ll}
$\begin{array}{l}\text { Substrate } \\
\text { type }\end{array}$ & Description \\
\hline $1 \mathrm{a}$ & $\begin{array}{l}\text { Soft bottom sediment with silt and mud } \\
1 \mathrm{~b}\end{array}$ \\
$\begin{array}{l}\text { Sand, including sandbanks } \\
2\end{array}$ & $\begin{array}{l}\text { Sand, gravel and small stones }<10 \mathrm{~cm} \text {. May also comprise } \\
\text { scattered stones }>10 \mathrm{~cm} \text { that cover }<10 \% \text { of the area }\end{array}$ \\
3 & $\begin{array}{l}\text { Sand, gravel and small stones }<10 \mathrm{~cm} \text {. May also comprise } \\
\text { scattered stones }>10 \mathrm{~cm} \text { that cover } 10-25 \% \text { of the area }\end{array}$ \\
4 & $\begin{array}{l}\text { Stones }>10 \mathrm{~cm} \text { with }>25 \% \text { coverage; also with sand, } \\
\text { gravel and scattered, small stones }\end{array}$ \\
\hline
\end{tabular}
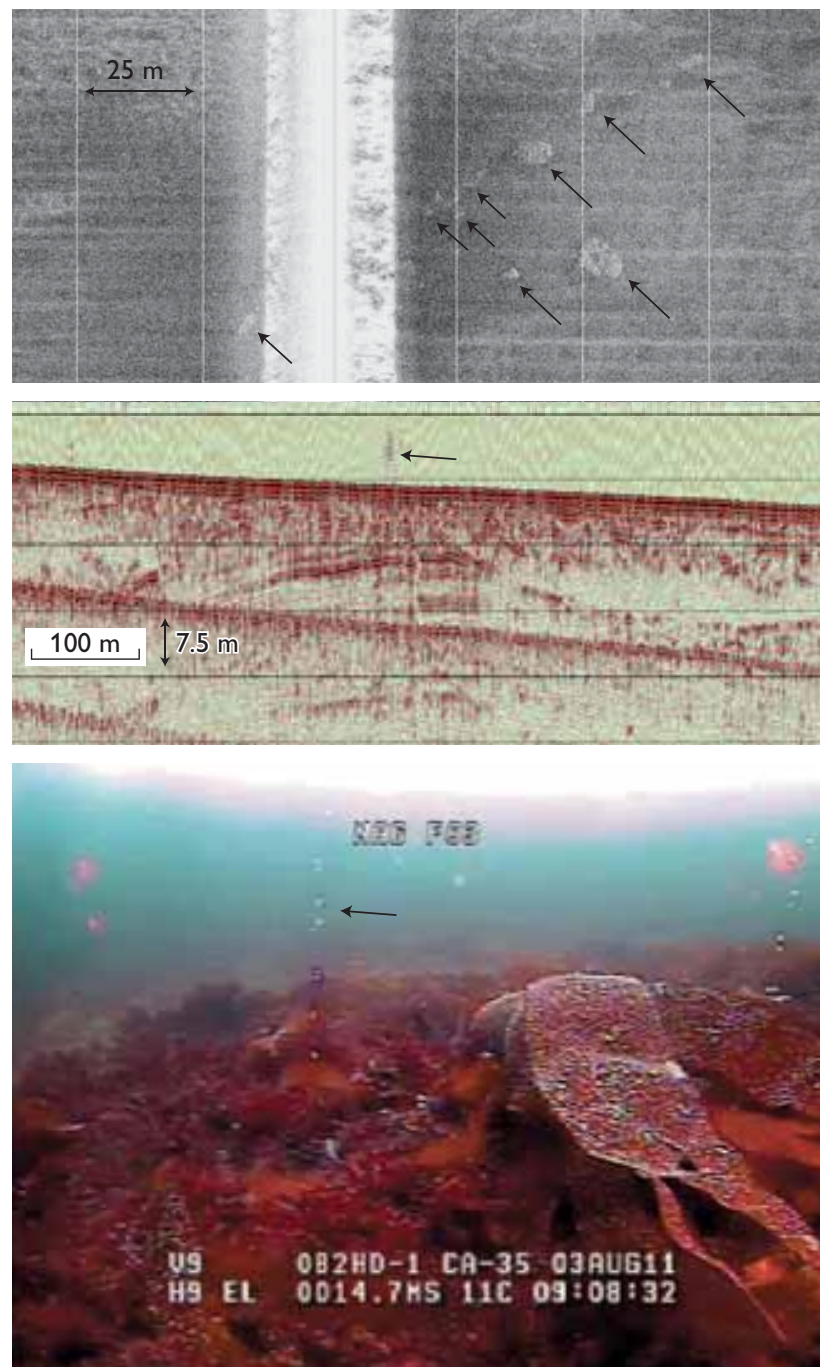

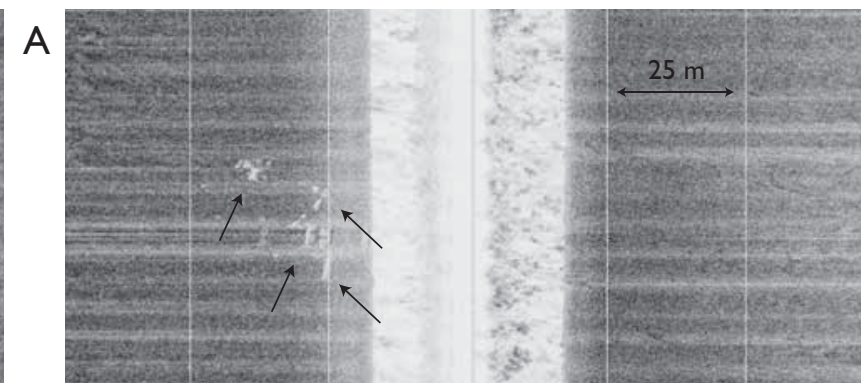

B

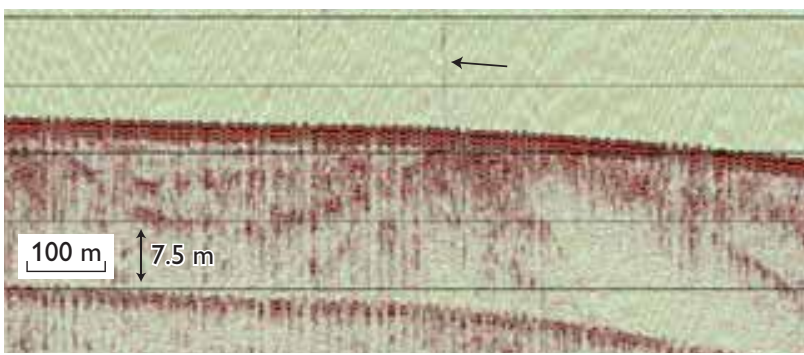

C

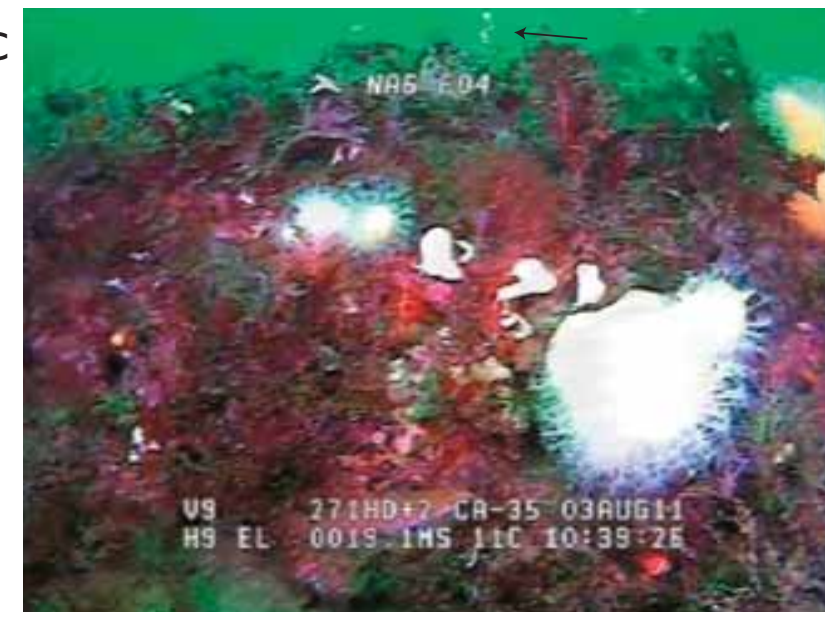

Fig. 3. Examples of 'bubbling reefs'. A: On side-scan images 'bubbling reefs' appear as small areas with lowered reflectivity (arrows). B: Shallow seismic sparker profiles with sites where the water column is disturbed by gas seeping out from the sediments (arrows). C: Snapshots from a video film taken with a camera mounted on a remotely operated vehicle. Gas bubbles are seen in the water column above the 'bubbling reefs' (arrows). The reefs have a rich epiflora and epifauna. 
some sand accumulations (substrate type $1 \mathrm{~b}$ ) are found in the eastern and southern parts.

'Bubbling reefs' form at sites where methane gas seeping up from Eemian and early Weichselian marine deposits has led to carbonate cementation of sand in the methane oxidation zone (Jensen et al. 1992; Laier et al. 1992). In some areas, cemented sand slabs have been exposed by subsequent erosion producing a hard substrate, which can be colonised by plants and animals that form a rich epiflora and epifauna. The geology, geochemistry and biology of the 'bubbling reefs' have been intensively studied, and their structure, origin and formation have been described by Jørgensen (1989), Jensen et al. (1992) and Laier \& Jensen (2007).

'Bubbling reefs' are fairly common in the Læsø Trindel region where they were discovered by chance by fishermen and sport divers. Some 'bubbling reefs' were recorded on sidescan images during previous surveys (Leth \& Al-Hamdani 2008), and additional occurrences of these structures were recorded in the side-scan data from 2011 (Fig. 2C). They are distinctive on the side-scan images (Fig. 3A), but can also be detected on shallow seismic profiles (Fig. 3B) where gasprone structures can be mapped, and sometimes gas bubbles can be seen in the water column. The 'bubbling reefs' occur mainly in areas with sandy seabed (substrate type $1 \mathrm{~b}$ ). The reefs support benthic communities rich in species (Fig. 3C) and have many cavities where animals can find shelter.

\section{Concluding remarks}

1. Habitat mapping using geophysical methods in combination with ground truth observations and sampling is a cost-effective means of mapping large seabed areas in a relatively short time.

2. Some Natura 2000 habitats such as the 'bubbling reefs' were originally discovered by chance by fishermen and sport divers. Side-scan surveying is an effective way to map this habitat type over larger areas.

3. The results obtained during this project provide information on the physical features and the habitat types of Læsø Trindel. These two elements are important to assess the current environmental status of marine waters as required by the Marine Strategy Framework Directive (table 1 in annex III).
4. Management of human activities in the marine environment requires a management plan that ensures habitat protection and at the same time enhances sustainable economic growth of the region. This project provides information on Natura 2000 areas for decision makers in Denmark.

\section{Acknowledgements}

The Danish Nature Agency is thanked for financing the project and for permission to publish the results. We also thank Orbicon $A / S$ for ground truth samples and films, and the captain and the crew of R/V Laura for help during the cruises.

\section{References}

European Commission 2007: Interpretation manual of European Union habitat, 142 pp. Brussels: European Commission, http:/lec.europa.eu/ environment/nature/legislation/habitatsdirective/docs/2007_07_im.pdf

European Union 1992: Council directive 92/43/EEC of 21 May 1992 on the conservation of natural habitats and of wild fauna and flora (Habitat Directive). Official Journal of the European Union L 206, 7-92, http://eur-lex.europa.eu/LexUriServ/LexUriServ.do?uri=OJ:L:1992: 206:0007:0050:EN:pdf

European Union 2008: Directive 2008/56/EC of the European Parliament and of the Council establishing a framework of community action in the field of marine environment policy (Marine Strategy Framework Directive). Official Journal of the European Union L 164, 19-40, http://eur-lex.europa.eu/LexUriServ/LexUriServ.do?uri=OJ:L:2008: 164:0019:0040:EN:pdf

Hansen, J.M. 1995: En ø’s opståen, kystdannelse og vegetationsudvikling: Naturlige og menneskeskabte landskaber på Læsø. Geologisk Tidsskrift 2, 1-74.

Hermansen, B. \& Jensen, J.B. 2000: Digitalt kort over havbundssedimenter omkring Danmark 1:500.000. Danmarks og Grønlands Geologiske Undersøgelse Rapport 2000/68 (CD-ROM).

Jensen, P., Aagaard, I., Burke Jr., R.A., Dando, P.R., Jørgensen, N.O., Kuijpers, A., Laier, T., O'Hara, S.C.M. \& Schmaljohann, R. 1992: 'Bubbling reefs' in Kattegat: Submarine landscapes of carbonate-cemented rocks support a diverse ecosystem at methane seeps. Marine Ecology Progress Series 83, 103-112.

Jørgensen, N.O. 1989: Holocene methane-derived, dolomite cemented sandstone pillars from the Kattegat, Denmark. Marine Geology 88, $71-81$.

Laier, T. \& Jensen, J.B. 2007: Shallow gas depth-contour of Skagerrak western Baltic Sea region. Geo-Marine Letters 27, 127-141.

Laier, T., Jørgensen, N.O., Buchardt, B., Cederberg, T. \& Kuijpers, A. 1992: Accumulation and seepages biogenic gas in northern Denmark. Continental Shelf Research 12, 1173-1186.

Leth, J.O. \& Al-Hamdani, Z. 2008: Mapping of the Natura 2000 Annex 1 habitats 1170 and 1180 in N Kattegat, combining acoustic and ground truth methods. In: Dinesen, G.E. (ed.): Mapping and modelling of marine habitats in the Baltic Sea region. BALANCE Interim Report 27, $75-89$.

\footnotetext{
Authors'address

Geological Survey of Denmark and Greenland, Øster Voldgade 10,DK-1350 Copenhagen K, Denmark. E-mail: azk@geus.dk
} 